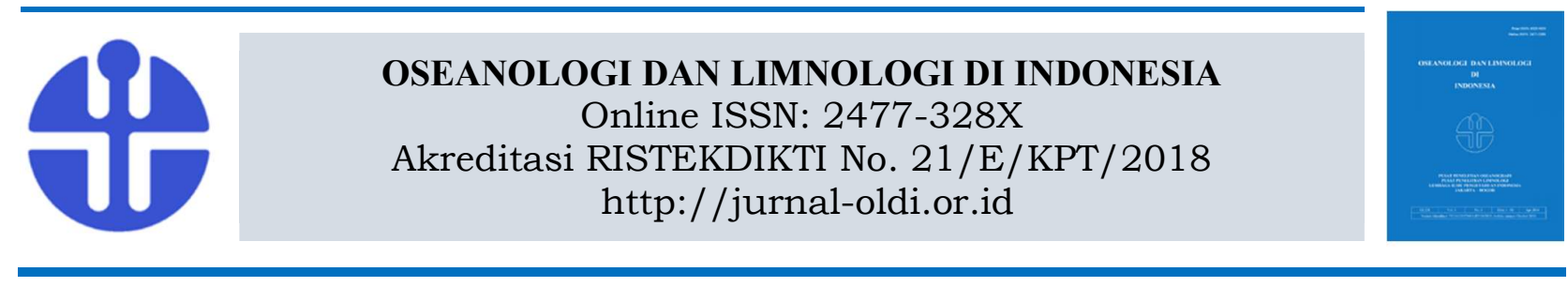

\title{
Produktivitas Primer Perairan Kolong Bekas Tambang Bauksit di Kota Tanjungpinang, Kepulauan Riau
}

\author{
Tri Apriadi' ${ }^{1}$, Risandi Dwirama Putra², dan Fadhliyah Idris ${ }^{2}$ \\ ${ }^{1)}$ Program Studi Manajemen Sumberdaya Perairan, Fakultas Ilmu Kelautan dan Perikanan, Universitas \\ Maritim Raja Ali Haji, Tanjungpinang, Kepri, Indonesia \\ ${ }^{2)}$ Program Studi Ilmu Kelautan, Fakultas Ilmu Kelautan dan Perikanan, Universitas Maritim Raja Ali Haji, \\ Tanjungpinang, Kepri, Indonesia \\ Email: tri.apriadi@umrah.ac.id
}

Submitted 8 February 2019. Reviewed 12 April 2019. Accepted 2 August 2019.

DOI: 10.14203/oldi.2019.v4i2.246

\begin{abstract}
Abstrak
Genangan bekas galian tambang (kolong) bauksit memiliki potensi untuk dimanfaatkan, khususnya sebagai area budidaya. Penelitian ini bertujuan untuk mengetahui produktivitas primer perairan, indeks ekologi fitoplankton, serta parameter fisika dan kimia perairan kolong bekas tambang bauksit di Kota Tanjungpinang, Kepulauan Riau. Penelitian dilakukan pada bulan April-Agustus 2018 pada dua kolong bekas tambang bauksit (stasiun 1 dan 2) di Senggarang, Kota Tanjungpinang. Parameter yang diamati meliputi kelimpahan serta indeks ekologi fitoplankton, produktivitas primer perairan, parameter fisika dan kimia perairan, serta nutrien $\mathrm{N}$ dan P. Berdasarkan hasil studi diketahui bahwa di perairan kolong bauksit di Kota Tanjungpinang terdapat tiga divisi fitoplankton yang terdiri dari tiga kelas dan delapan genera. Mougeotia sp. merupakan jenis fitoplankton yang dominan. Perairan bekas galian bauksit ini tergolong labil dan komunitas fitoplankton dalam kondisi tertekan akibat adanya dominasi oleh spesies tertentu. Disamping itu, perairan kolong ini tergolong muda (genangan $<5$ tahun) sehingga memiliki produktivitas primer yang rendah dengan tingkat kesuburan rendah (oligotrofik). Laju produksi karbon oleh fitoplankton di stasiun $2(1,23 \mathrm{mgC} / \mathrm{L} / \mathrm{hari}$ ) lebih tinggi dibandingkan stasiun $1(0,25 \mathrm{mgC} / \mathrm{L} / \mathrm{hari})$. Parameter fisika dan kimia perairan kolong bauksit yang dikaji masih memenuhi baku mutu untuk kegiatan budidaya air tawar, kecuali parameter $\mathrm{pH}$ dan amonia.
\end{abstract}

Kata kunci: bauksit, fitoplankton, kolong, produktivitas primer, Tanjungpinang

\begin{abstract}
Primary Productivity on Abandoned Bauxite Mining Pits of Tanjungpinang City, Riau Islands. The abandoned bauxite mining pits in Bintan Island have a good opportunity to be developed, especially as an aquaculture area. The objective of this study was to determine the primary productivity of the waters, phytoplankton ecological index, and physical and chemical parameters of the bauxite post-mining ponds in Tanjungpinang City, Riau Islands. The study was conducted in April-August 2018 in two bauxite post-mining ponds (station 1 and 2) in Senggarang, Tanjungpinang City. The parameters observed were the abundance and ecological index of phytoplankton, aquatic primary productivity, physical and chemical parameters of the waters, and nutrients, $N$ and P. From the study it was found that there were three phytoplankton divisions, consisted of three classes and eight genera. Mougeotia sp. was the dominant species of phytoplankton. The abandoned bauxite mining pits were classified as labile and the phytoplankton communities were under environmental stress due to the dominance of certain species. The abandoned bauxite mining pits were classified as young (inundation $<5$ years), low primary productivity, as well as oligotrophic waters. Net
\end{abstract}


Apriadi et al.

primary productivity in station 2 was higher than station 1, i.e. $1,23 \mathrm{mgC}^{-1}$ day $y^{-1}$ and $0,25 \mathrm{mgC} L^{-1}$ day $y^{-1}$, respectively. The physical and chemical parameters of the bauxite post-mining ponds studied met the quality standards for freshwater aquaculture activities, except for $\mathrm{pH}$ and ammonia

Keywords: bauxite, phytoplankton, post-mining ponds, primary productivity, Tanjungpinang

\section{Pendahuluan}

Pulau Bintan dikenal sebagai salah satu daerah penghasil bauksit di Indonesia. Saat ini penambangan bauksit komersil di Pulau Bintan sudah dibatasi. Proses penambangan bauksit di Pulau Bintan menyisakan genangan air (kolong) yang umumnya juga dijumpai pada daerah paskatambang timah dan pasir. Genangan air yang terbentuk ini dapat berasal dari proses pencucian bijih bauksit yang juga menghasilkan red mud yaitu endapan lumpur berwarna merah yang merupakan sisa pencucian bijih bauksit (Zulfikar, 2015; Zulfikar et al., 2015).

Ekosistem perairan kolong yang baru terbentuk ini umumnya memiliki struktur komunitas fitoplankton yang masih belum stabil, dicirikan dengan kelimpahan fitoplankton yang rendah, indeks keanekaragaman rendah, keseragaman rendah-sedang dan dominasi sedang (Apriadi \& Ashari 2018). Produktivitas yang rendah ini diakibatkan oleh terbatasnya sediaan nutrien. Aryani dan Apriadi (2018) melaporkan bahwa terdapat makrofita pioner berupa purun (Eleocharis sp.) yang terdapat pada beberapa kolong bauksit di Pulau Bintan. Menurut informasi yang diperoleh dari masyarakat, kolong ini tergolong muda (periode genangan $<5$ tahun). Berdasarkan hasil pengamatan diketahui bahwa kolong bauksit di Pulau Bintan ini umumnya belum dimanfaatkan secara optimal, padahal diduga mempunyai potensi besar untuk dikembangkan, salah satunya dalam sektor perikanan. Potensi kolong bauksit di Pulau Bintan sudah mulai dikaji oleh para peneliti. Kajian terdahulu yang telah dilakukan yaitu analisis logam berat serta mineral makro dan mikro pada sedimen (Putra et al., 2018), keanekaragaman fitoplankton (Apriadi \& Ashari, 2018), serta mikroalgae epifit (Aryani \& Apriadi, 2018).

Produktivitas primer perairan merupakan dasar dalam pengelolaan suatu ekositem perairan (Barber \& Hitling, 2002), termasuk ekosistem perairan yang baru terbentuk seperti halnya kolong bauksit. Kajian mengenai produktivitas primer di kolong Bauksit Pulau Bintan belum dilaporkan. Kajian ini bertujuan untuk mengetahui nilai parameter fisika-kimia, kelimpahan fitoplankton, indeks biologi biota, serta produktivitas primer perairan bekas galian bauksit Senggarang, Kota Tanjungpinang. Hasil kajian ini merupakan informasi dasar, mengingat belum ada kajian serupa di kolong bauksit Pulau Bintan. Selain itu, hasil kajian ini diharapkan dapat menjadi dasar pengembangan potensi pemanfaatan kolong bauksit di Kota Tanjungpinang, Kepulauan Riau.

\section{Metode Penelitian}

Penelitian ini dilaksanakan pada bulan April-Agustus 2018. Pengamatan dilakukan sebanyak tiga kali, data yang diperoleh kemudian dihitung nilai rata-rata. Lokasi penelitian di perairan kolong tambang bauksit di Senggarang, Kota Tanjungpinang, Pulau Bintan, Provinsi Kepulauan Riau. Peta lokasi penelitian disajikan pada Gambar 1. Analisis fitoplankton dilakukan di laboratorium Fakultas Ilmu Kelautan dan Perikanan, Universitas Maritim Raja Ali Haji. Analisis nutrien meliputi $\mathrm{N}\left(\mathrm{NH}_{3}^{-}, \mathrm{NO}_{2}^{-}, \mathrm{NO}_{3}^{-}\right)$dan $\mathrm{P}$ (total fosfat) di lakukan di Laboratorium Balai Teknik Kesehatan Lingkungan dan Pengendalian Penyakit Kelas 1 Batam.

Pengambilan sampel dilakukan pada dua kolam bekas penambangan bauksit (kolong) di Senggarang, Kota Tanjungpinang, Pulau Bintan. Pemilihan dua kolong bauksit didasari atas perbedaan luasan dan keberadaan makrofita pionir yaitu purun (Eleocharis sp.) yang merupakan tumbuhan air tipe mencuat. Kolong pertama (stasiun 1) memiliki luasan $6.777,19 \mathrm{~m}^{2}$, sedangkan luasan kolong kedua (stasiun 2) yaitu $11.314,06 \mathrm{~m}^{2}$. Luasan sebaran purun di stasiun 2 yaitu $10.268,72 \mathrm{~m}^{2}$ (91\% dari luasan kolong) sedangkan di stasiun 1 hanya 1.567,06 $\mathrm{m}^{2}(23 \%$ dari luasan kolong). Stasiun 1 terdiri atas tiga titik sampling, dan stasiun 2 sebanyak enam titik sampling (Gambar 1). Titik sampling pada setiap stasiun ditentukan secara acak. 


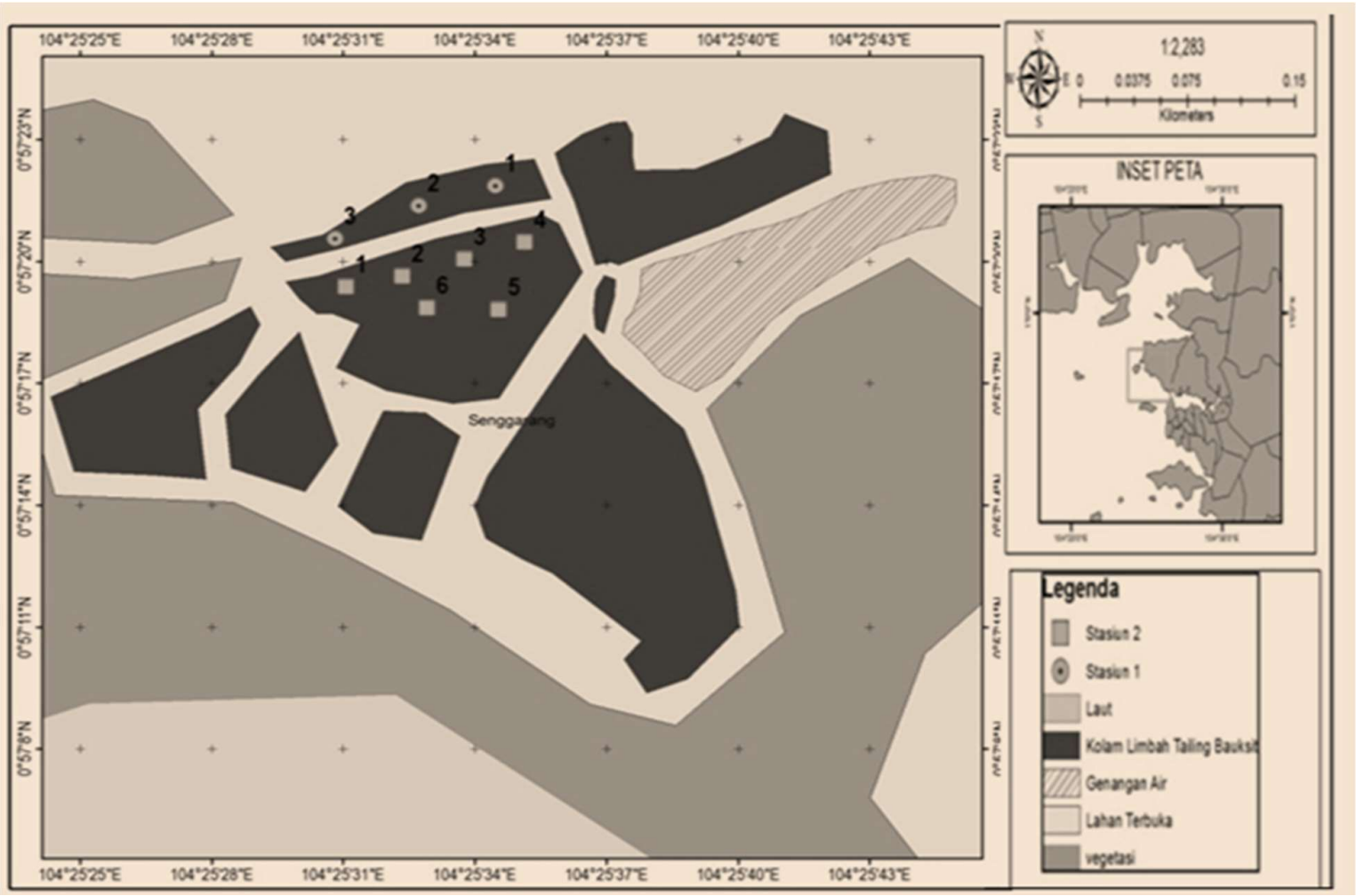

Gambar 1. Peta lokasi penelitian.

Figure 1. Sampling site.

Pengukuran parameter insitu perairan $\mathrm{pH}$, suhu, DO (menggunakan multitester), kecerahan (menggunakan secchi disc), serta pengambilan sampel air dilakukan pada pukul 09.00-14.00 WIB. Sampel air untuk keperluan analisis nutrien $\left(\mathrm{NH}_{3}{ }^{-}\right.$, $\mathrm{NO}_{2}{ }^{-}, \mathrm{NO}_{3}{ }^{-}$, total fosfat) diambil dengan mempergunakan Vandorn water sampler pada kolom air, kemudian diawetkan dengan $\mathrm{H}_{2} \mathrm{SO}_{4}$ hingga $\mathrm{pH}<2$ dan didinginkan pada suhu $4^{\circ} \mathrm{C}$ (APHA, 2012). Sampel fitoplankton diambil sebanyak $100 \mathrm{~L}$ dengan mempergunakan plankton net nomor 25 (ukuran $40 \mu \mathrm{m}$ ) pada kedalaman eufotik (berdasarkan hasil pengukuran kecerahan dengan mempergunakan secchi disc). Fitoplankton diawetkan dengan lugol 10\% (Pottasium Iodida/KI, kristal iodine, serta asam asetat sebagai pengawet) untuk selanjutnya dianalisis di laboratorium (APHA, 2012). Untuk pengukuran produktivitas primer perairan, botol gelap-terang diletakkan pada kedalaman eufotik untuk inkubasi selama 2 jam, dan kemudian diukur kandungan oksigennya menggunakan metode Winkler (APHA, 2012).

\section{Analisis Data}

\section{Produktivitas Primer Perairan}

Berdasarkan metode botol gelap terang, maka akan diperoleh konsentrasi oksigen pada botol inisial (I), botol gelap (D), serta botol terang (L). Produktivitas primer perairan dihitung dengan rumus Wetzel dan Likens dalam Hardiyanto et al. (2012).

Respirasi komunitas plankton,

$$
\mathrm{R}=\mathrm{I}-\mathrm{D} \mathrm{mgO}_{2} / \mathrm{L} / \text { hari }
$$

Produksi primer bersih,

$$
\mathrm{NPP}=\mathrm{L}-\mathrm{I} \mathrm{mg} \mathrm{O}_{2} / \mathrm{L} / \text { hari }
$$

Produksi primer kotor,

$\mathrm{GPP}=\mathrm{L}-\mathrm{D} \mathrm{mgO}_{2} / \mathrm{L} /$ hari

Selanjutnya, untuk menentukan nilai GPP dan NPP dalam karbon, maka dilakukan konversi dari oksigen menjadi karbon (12/32) dan dikalikan dengan koefisien fotosintesis sebesar 1,2 (Ryther dalam Kaswadji et al., 1993; Alianto et al., 2008).

\section{Kelimpahan fitoplankton}

Fitoplankton diamati menggunakan metode sensus dengan bantuan mikroskop dan sedgewick rafter counting chamber (SRC). Identifikasi fitoplankton menggunakan buku identifikasi plankton Illustrations of the Freshwater Plankton of Japan (Mizuno, 1979) dan The Marine and Fresh-water Plankton (Davis, 1955). Rumus kelimpahan fitoplankton sebagai berikut (APHA, 2012).

$$
\mathrm{N}=\mathrm{n} \times \frac{\mathrm{A}}{\mathrm{a}} \times \frac{\mathrm{v}}{\mathrm{vc}} \times \frac{1}{\mathrm{~V}}
$$




\section{Apriadi et al.}

Keterangan:

$$
\begin{array}{lll}
\mathrm{N} & : & \text { kelimpahan fitoplankton }(\mathrm{sel} / \mathrm{L}) \\
\mathrm{n} & : & \text { jumlah individu fitoplankton yang } \\
& \text { teramati (sel) } \\
\mathrm{A} & : & \text { luas cover glass }\left(\mathrm{mm}^{2}\right) \\
\mathrm{a} & : & \text { luas bidang pandang }\left(\mathrm{mm}^{2}\right) \\
\mathrm{V} & : & \text { volume air terkonsentrasi }(\mathrm{mL}) \\
\mathrm{vc} & : \text { volume air di bawah } \operatorname{cover} \text { glass }(\mathrm{mL}) \\
\mathrm{V} & : \text { volume air yang disaring }(\mathrm{L})
\end{array}
$$

\section{Indeks Keanekaragaman $\left(H^{\prime}\right)$}

Indeks keanekaragaman dihitung menggunakan rumus Indeks Shannon-Wiener (Krebs, 2014; Odum, 1993).

$$
\boldsymbol{H}^{\prime}=-\sum_{i=1}^{s} p_{i} \ln p_{i}
$$

Keterangan:

$\mathrm{H}^{\prime} \quad$ : indeks keanekaragaman

$\mathrm{p}_{\mathrm{i}} \quad$ : proporsi spesies ke-i $\left(\mathrm{n}_{\mathrm{i}} / \mathrm{N}\right)$

$\mathrm{n}_{\mathrm{i}} \quad$ : jumlah individu spesies ke-i

$\mathrm{N} \quad$ : jumlah total individu

$\mathrm{S} \quad$ : jumlah spesies

Kriteria nilai $\mathrm{H}^{\prime}$ sebagai berikut:

$0<\mathrm{H}^{\prime}<2,302 \quad$ : keanekaragaman rendah

$2,302<\mathrm{H}^{\prime}<6,907 \quad$ : keanekaragaman sedang

$\mathrm{H}^{\prime}>6,907$ : keanekaragaman tinggi

\section{Indeks Keseragaman}

Indeks keseragaman digunakan untuk melihat tingkat kemerataan jenis dalam suatu komunitas. Indeks keseragaman dihitung menggunakan rumus Indeks Evenness (Krebs, 2014; Odum, 1993).

$$
\begin{array}{ll} 
& \multicolumn{1}{c}{\mathbf{E}=\frac{\mathbf{H}^{\prime}}{\mathbf{H} \text { maks }}} \\
\mathrm{E} & : \text { indeks keseragaman } \\
\mathrm{H}^{\prime} & : \text { indeks keanekaragaman } \\
\mathrm{H} \text { maks } & : \text { In S (S merupakan jumlah spesies) }
\end{array}
$$

\section{Indeks Dominansi}

Indeks dominansi dihitung menggunakan rumus Indeks Simpson (Krebs, 2014; Odum, 1993).

$$
\begin{gathered}
\qquad \boldsymbol{C}^{\prime}=\sum_{i=1}^{s}\left(p_{i}\right)^{2} \\
\boldsymbol{C}^{\prime} \quad \text { indeks dominansi } \\
\mathrm{p}_{\mathrm{i}} \quad \text { : proporsi spesies ke-i }\left(\mathrm{n}_{\mathrm{i}} / \mathrm{N}\right) \\
\mathrm{s} \quad \text { jumlah spesies } \\
\text { Hasil }
\end{gathered}
$$

\section{Hasil}

\section{Nilai Parameter Fisika dan Kimia Perairan Kolong Penambangan Buksit}

Hasil pengukuran terhadap beberapa parameter fisika dan kimia perairan di bekas galian bauksit pada lokasi studi memberikan indikasi bahwa secara umum parameter fisika dan kimia perairan masih memenuhi baku mutu untuk peruntukan kegiatan budidaya air tawar (Tabel 1). Namun demikian, nilai $\mathrm{pH}$ di perairan kolong bauksit ini tergolong asam, $\mathrm{pH}$ sangat rendah serta nilai amonia $\left(\mathrm{NH}_{3}{ }^{-}\right)$sedikit melebihi ambang batas baku mutu yang dipersyaratkan.

\section{Kelimpahan Fitoplankton}

Berdasarkan hasil identifikasi, pada bekas galian bauksit di Senggarang ditemukan tiga divisi fitoplankton yang terdiri dari tiga kelas dan delapan genera (Tabel 2).

\section{Indeks Ekologi Fitoplankton}

Indeks keanekaragaman pada kedua stasiun tergolong rendah, mengindikasikan bahwa jumlah spesies fitoplankton yang terdapat di kolam pengendapan limbah tailing bauksit tersebut sedikit. Indeks keseragaman stasiun 1 dan stasiun 2 tergolong rendah dengan nilai yang mendekati 0 , sedangkan indeks dominansi tergolong tinggi (Tabel 3).

\section{Produktivitas Primer}

Laju respirasi, NPP, dan GPP berdasarkan oksigen terlarut di perairan pada stasiun 2 lebih besar dari stasiun 1 (Gambar 2). Laju produksi karbon (NPP) oleh fitoplankton di stasiun $2(1,23$ $\mathrm{mgC} / \mathrm{L} / \mathrm{hari}$ ) lebih tinggi dibandingkan stasiun 1 $(0,25 \mathrm{mgC} / \mathrm{L} /$ hari) (Gambar 3). 
Oseanologi dan Limnologi di Indonesia 2019 4(2):113-121

Tabel 1. Nilai rata-rata parameter fisika dan kimia perairan di kolong penambangan bauksit Senggarang, Kota Tanjungpinang, Kepulauan Riau.

Table 1. Physico-chemical parameters of abandoned bauxite mining pits in Senggarang, Tanjungpinang City, Riau Islands.

\begin{tabular}{lccc}
\hline \multicolumn{1}{c}{ Parameter } & Station 1 & Station 2 & Standard * \\
\hline Temperature $\left({ }^{\circ} \mathrm{C}\right)$ & $27.9 \pm 0.21$ & $28.5 \pm 0.48$ & Deviation 3 from natural condition \\
Visibility $(\mathrm{cm})$ & $130.67 \pm 73.92$ & $126.67 \pm 51.99$ & - \\
Turbidity (NTU) & $0.22 \pm 0.05$ & $0.55 \pm 0.24$ & - \\
Depth $(\mathrm{cm})$ & $130.67 \pm 73.92$ & $126.67 \pm 51.99$ & - \\
$\mathrm{pH}$ & $3.64 \pm 2.1$ & $3.77 \pm 0.02$ & $6-9$ \\
$\mathrm{DO}\left(\mathrm{mg} \mathrm{L}^{-1}\right)$ & $7.60 \pm 4.93$ & $7.43 \pm 0.19$ & $>4$ \\
$\mathrm{NH}_{3}^{-}\left(\mathrm{mg} \mathrm{L}^{-1}\right)$ & $0.07 \pm 0.04$ & $0.03 \pm 0.01$ & - \\
$\mathrm{NO}_{2}^{-}\left(\mathrm{mg} \mathrm{L}^{-1}\right)$ & $0.00 \pm 0.00$ & $0.00 \pm 0.00$ & 0.06 \\
$\mathrm{NO}_{3}^{-}\left(\mathrm{mg} \mathrm{L}^{-1}\right)$ & $0.53 \pm 0.02$ & $0.38 \pm 0.34$ & 10 \\
$\mathrm{P} \mathrm{Total}\left(\mathrm{mg} \mathrm{L}^{-1}\right)$ & $<0.02 \pm 0.00$ & $0.06 \pm 0.05$ & 0.2 \\
\hline
\end{tabular}

*Baku mutu berdasarkan Peraturan Pemerintah. No. 82 Tahun 2001 Kelas II untuk kegiatan perikanan

*Standard based on Indonesian Government Regulation. No. 82 year 2001, $2^{\text {nd }}$ Category for fisheries activity

Tabel 2. Kelimpahan fitoplankton di kolong penambangan bauksit Senggarang, Kota Tanjungpinang, Kepulauan Riau.

Table 2. Phytoplankton abundance at bauxite post-mining ponds in Senggarang, Tanjungpinang City, Riau Islands.

\begin{tabular}{llrr}
\hline \multirow{2}{*}{ Divisi } & \multicolumn{1}{c}{ Species } & \multicolumn{2}{c}{ Abundance (cell L $\mathbf{~}^{-1}$ ) } \\
\cline { 2 - 4 } Bacillariophyta & Station 1 & \multicolumn{1}{c}{ Station 2 } \\
& Rhizosolenia sp. & 41.07 & $7,736.07$ \\
& Navicula sp. & 19.15 & 17.56 \\
& Nitzchia sp. & 41.71 & 24.49 \\
& Istmia sp. & 188.24 & $69,762.54$ \\
\hline Charophyta & Mougeotia sp. & $9,082.06$ & $2,518,508.49$ \\
& Penium sp. & 130.29 & $111,042.40$ \\
& Melosira sp. & 21.17 & 27.32 \\
\hline Chrysophyta & Ochromonas sp. & 15.11 & $10.340,99$ \\
\hline & Total & $9,538.81$ & $2,717,459.87$ \\
\hline
\end{tabular}

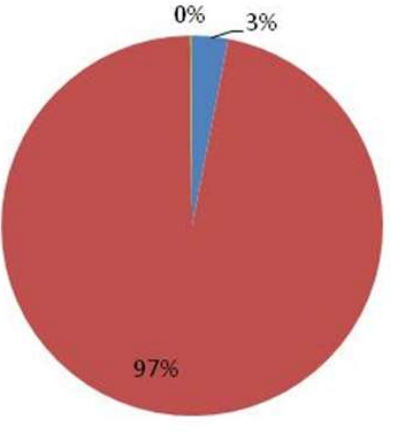

Station 1

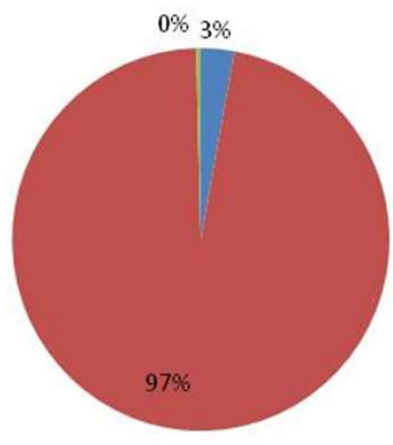

Station 2
- Bacillariophyceae

n Charophyceae

- Chrysophyceae

Gambar 1. Komposisi fitoplankton berdasarkan kelas di bekas galian bauksit Senggarang, Kota Tanjungpinang, Kepulauan Riau.

Figure 1. Phytoplankton compotition based on class at bauxite post-mining ponds in Senggarang, Tanjungpinang City, Riau Islands. 
Apriadi et al.

Tabel 3. Indeks ekologi fitoplankton di bekas galian bauksit Senggarang, Kota Tanjungpinang, Kepulauan Riau.

Table 3. Ecological index of phytoplankton at abandoned bauxite mining pits in Senggarang, Tanjungpinang City, Riau Islands.

\begin{tabular}{ccc}
\hline Index & Station 1 & Station 2 \\
\hline \multirow{2}{*}{ Diversity (H') } & $\begin{array}{c}0.27 \\
\text { (low) }\end{array}$ & $\begin{array}{c}0.33 \\
(\text { low })\end{array}$ \\
\hline \multirow{2}{*}{ Similarity (E) } & 0.13 & 0.16 \\
& $($ low) & (low) \\
\hline \multirow{2}{*}{ Dominance (C) } & 0.91 & 0.86 \\
& (high) & (high) \\
\hline
\end{tabular}

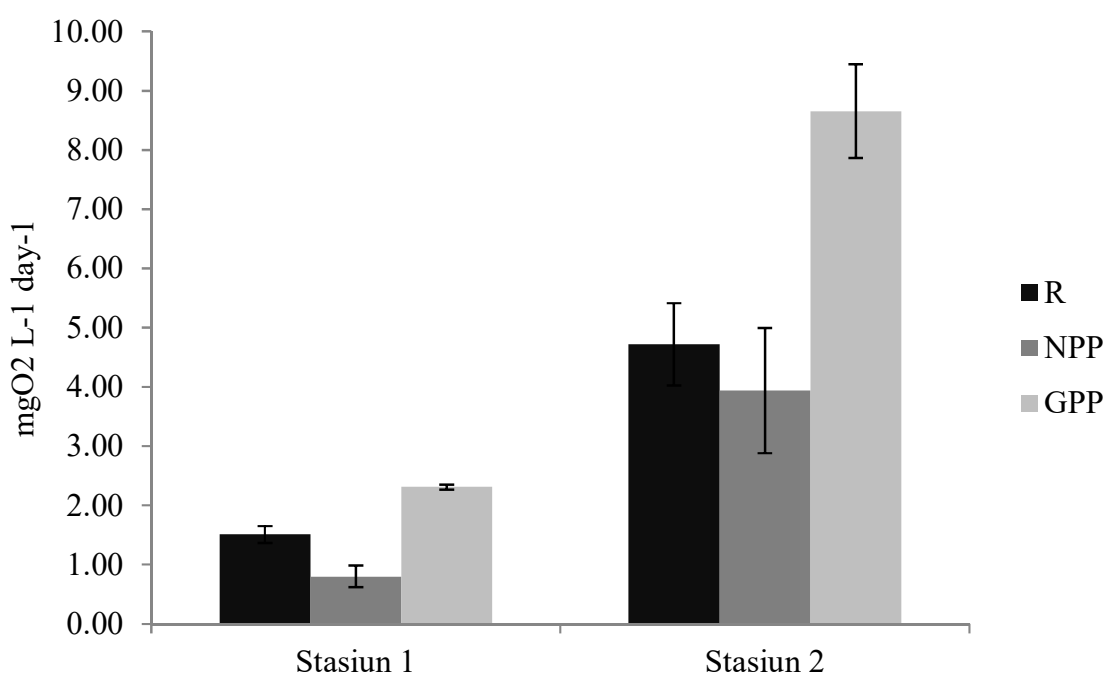

Gambar 2. Laju respirasi (R), produktivitas primer bersih (NPP), dan produktivitas primer kotor (GPP) berdasarkan oksigen terlarut di perairan kolong bauksit Senggarang, Kota Tanjungpinang, Kepulauan Riau.

Figure 2. Respiration rate (R), net primary productivity (NPP), and gross primary productivity (GPP) based on dissolved oxygen at abandoned bauxite mining pits in Senggarang, Tanjungpinang City, Riau Islands.

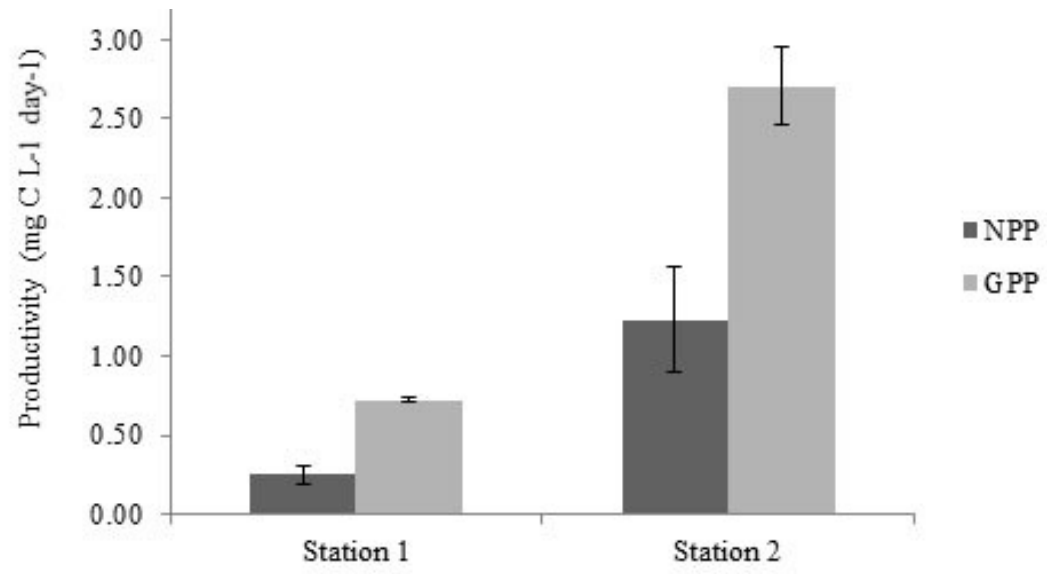

Gambar 3. Laju produktivitas primer bersih (NPP) dan produktivitas primer kotor (GPP) di perairan kolong Bauksit Senggarang, Kota Tanjungpinang, Kepulauan Riau.

Figure 3. Net primary productivity (NPP) and gross primary productivity (GPP) at abandoned bauxite mining pits in Senggarang, Tanjungpinang City, Riau Islands. 


\section{Pembahasan}

Sebagai ekosistem yang baru terbentuk, kestabilan ekologis (parameter fisika-kimia perairan, serta biologi) di perairan kolong bauksit dipengaruhi oleh durasi penggenangan. Kolong yang memiliki masa penggenangan lebih lama akan cenderung memiliki kestabilan ekologis yang lebih baik dibandingkan kolong yang baru tergenang (Puspita et al., 2005). Parameter perairan yang menjadi ciri khas di perairan kolong adalah nilai $\mathrm{pH}$ yang rendah. Hal ini serupa dengan hasil penelitian terdahulu pada kolong bauksit di Pulau Bintan (Putra et al., 2018; Sembiring, 2008; Zulfikar, 2015; Zulfikar et al., 2015). Dalam proses penambangan bauksit, proses pencucian terhadap tanah bagian atas (topsoil) menyebabkan tailing bauksit sedikit mengandung tanah, dan didominasi oleh batu kerikil dan pasir. Kandungan air yang terikat pada tanah dan topsoil berupa $\mathrm{pH}_{2} \mathrm{O}$ dan $\mathrm{pH} \mathrm{KCl}$. Tekstur kerikil dan pasir hanya sedikit dapat menahan air. Hal ini dapat menyebabkan penurunan $\mathrm{pH} \mathrm{H}_{2} \mathrm{O}$ dan $\mathrm{pH} \mathrm{KCl}$ yang terdapat di tailing bauksit (Sembiring, 2008).

Hasil penelitian terdahulu oleh Putra et al. (2018) memberikan informasi bahwa $\mathrm{pH}$ perairan kolong bauksit tergolong asam $(4,94-6,36)$. Hal ini diduga akibat pengaruh kandungan beberapa logam pada limbah tailing bauksit. Besi (Fe) merupakan logam yang memiliki konsentrasi tertinggi pada limbah tailing bauksit di Pulau Bintan yaitu 0,14-0,74 mg/L di daerah Wacopek (Zulfikar 2015) dan 0,61-1,45 mg/L di Sei Carang (Zulfikar et al., 2015). Borra et al. (2016) menyebutkan bahwa mineral minor $\mathrm{Fe}$ juga terkandung pada bijih bauksit yaitu $\mathrm{Fe}_{2} \mathrm{O}_{3}$ (hematit) dan $(\mathrm{FeO}(\mathrm{OH}))$ (geotit). Tingginya konsentrasi besi oksida menyebabkan warna merah pada limbah tailing bauksit (red mud). Berdasarkan penelitian Zulfikar (2015), nilai pH pada tailing/red mud bauksit tergolong rendah yaitu berkisar antara 4,08 - 4,72.

Keberadaan amonia dalam perairan umumnya dihasilkan dari proses dekomposisi bahan organik yang mengandung nitrogen. Sumber bahan organik yang terkandung di perairan kolong bauksit yang dikaji ini bersumber dari fitoplankton maupun serasah tumbuhan air pionir (Eleocharis sp.) yang umumnya dijumpai pada genangan bekas galian bauksit. Stasiun 2 memiliki konsentrasi amonia yang lebih kecil dan fosfor yang lebih besar bila dibandingkan dengan stasiun 1. Fosfor umumnya menjadi faktor pembatas di perairan tawar (Schindler, 1977). Elser et al. (2007) menyebutkan bahwa fitoplankton pada perairan tawar lentik responsif terhadap nutrein $\mathrm{N}$ dan $\mathrm{P}$ (dalam berbagai bentuk), dan alga bentik sangat dibatasi oleh keberadaan nutrien $\mathrm{P}$ daripada $\mathrm{N}$. Jumlah fosfor yang sedikit di perairan namun sangat dibutuhkan dan dapat memengaruhi produktivitas primer di perairan. Konsentrasi oksigen terlarut yang cukup tinggi pada dua lokasi studi menyebabkan amonia segera teroksidasi menjadi nitrat melalui proses nitrifikasi (Keeney, 1973). Hal ini terlihat dari kandungan nitrat yang cukup tinggi.

Kelimpahan fitoplankton pada stasiun 2 lebih tinggi dibandingkan stasiun 1 . Hal ini diduga karena stasiun 2 memiliki kondisi yang lebih baik dibandingkan stasiun 1, mengingat periode genangan ini tergolong muda ( $<5$ tahun). Tepi perairan stasiun 2 ditumbuhi lebih banyak Eleocharis sp. dibandingkan stasiun 2 dan diduga serasah tumbuhan pionir ini dapat menjadi penyumbang nutrien di genangan tersebut. Mougeotia sp. merupakan jenis yang dominan di kedua stasiun, sejalan dengan hasil penelitian Apriadi dan Ashari (2008). Jenis ini tergolong ke dalam kelas Charophyceae yang juga mendominasi kedua stasiun (Gambar 1). Kelimpahan Mougeotia sp. yang tinggi diduga karena perairan genangan bekas galian bauksit merupakan habitat yang cocok untuk pertumbuhan jenis ini. Mougeotia sp. mampu bertahan pada kondisi perairan asam, dan umumnya memerlukan suhu air yang hangat dengan intensitas cahaya yang cukup (Graham et al., 1996).

Rendahnya jumlah jenis fitoplankton yang ditemukan diduga karena kondisi ekologis perairan yang kurang sesuai, sehingga hanya jenis tertentu yang mampu hidup dan berkembang di perairan tersebut. Berdasarkan informasi yang diperoleh dari warga sekitar, diketahui bahwa kolong ini terbentuk kurang dari lima tahun. Wardoyo dan Ismail (1998) dan Puspita et al. (2005) menyebutkan bahwa kolong yang berusia kurang dari lima tahun tergolong kolong muda (kandungan unsur hara masih sedikit, biota hampir tidak ada).

Rendahnya indeks keseragaman menggambarkan bahwa jumlah sel atau individu tiap spesies cenderung berbeda atau tidak seimbang. Nilai indeks dominansi tergolong tinggi dan mengindikasikan bahwa terdapat spesies yang mendominasi, yaitu Mougeotia sp. Kondisi perairan dengan indeks dominansi yang tinggi menggambarkan bahwa komunitas fitoplankton dalam kondisi tertekan oleh kondisi lingkungan. Huszar dan Reynolds (1997) menyebutkan bahwa terdapat pergantian dominansi spesies fitoplankton sebagai respon terhadap perubahan kondisi lingkungan yang terjadi secala berkala pada danau rawa banjiran.

Kelimpahan fitoplankton stasiun 2 yang jauh lebih besar dibandingkan stasiun 1 diduga menjadi 
penyebab tingginya nilai NPP dan GPP. Fitoplankton sebagai produsen primer akan menghasilkan oksigen terlarut melalui proses fotosintesis (Asriyana \& Yuliana, 2012). Semakin tinggi kelimpahan fitoplankton, semakin banyak DO diproduksi, semakin tinggi pula GPP dan NPP.

Jika diperhatikan, laju respirasi di kedua stasiun menunjukkan nilai yang lebih besar dibandingkan NPP. Nilai rasio NPP:respirasi pada stasiun 1 dan 2 berturut-turut adalah 0,53 dan 0,83. Nilai rasio NPP:respirasi $>1$ mengindikasikan bahwa fotosintesis oleh fitoplankton berlangsung optimal, sebaliknya nilai NPP:respirasi <1 menunjukkan bahwa aktivitas fotosintesis fitoplankton rendah dan dapat menurunkan produktivitas primer (Dash et al., 2011). Nilai rasio NPP:respirasi $<1$ pada kedua stasiun memberikan gambaran bahwa perairan kolong bauksit ini belum bisa menghasilkan laju produktivitas primer yang maksimal. Indikasi dari fenomena ini adalah perairan bekas galian bauksit memiliki produktivitas primer yang rendah dengan tingkat kesuburan rendah (oligotrofik). Hal ini sejalan dengan pernyataan Carignan et al. (1998) bahwa danau oligotrofik memiliki laju respirasi yang lebih tinggi dari pada laju produksi.

\section{Kesimpulan}

Parameter fisika dan kimia perairan yang diukur pada bekas galian bauksit di Senggarang< Kota Tanjungpinang, Kepulauan Riau masih memenuhi baku mutu untuk kegiatan perikanan. Perairan bekas galian bauksit di Senggarang memiliki tiga divisi fitoplankton yang terdiri dari tiga kelas dan delapan genera. Mougeotia sp. merupakan jenis fitoplankton yang dominan. Perairan bekas galian bauksit di Senggarang tergolong labil dan komunitas fitoplankton dalam kondisi tertekan akibat adanya dominasi spesies. Bekas galian bauksit memiliki produktivitas primer yang rendah dengan tingkat kesuburan rendah (oligotrofik).

\section{Ucapan Terima Kasih}

Ucapan terima kasih disampaikan kepada Kementerian Riset, Teknologi, dan Pendidikan Tinggi yang telah mendanai penelitian ini melalui Hibah penelitian Dosen Pemula tahun 2018. Penulis juga menghaturkan terima kasih kepada Tina Sitorus, Irvan Hasan Ashari, Nurul Hidayah Eka Fitri, Siti Hidayani, serta Ismail yang telah membantu dalam kegiatan pengambilan sampel di lapangan serta analisis fitoplankton.

\section{Referensi}

Alianto, Adiwilaga, E. M., \& Damar, A. (2008). Produktivitas Primer Fitoplankton dan Keterkaitannya dengan Unsur Hara dan Cahaya di Perairan Teluk Banten. Jurnal Ilmu-ilmu Perairan dan Perikanan Indonesia, 15(1), 21-26.

American Public Health Association. (2012). Standard Methods for the Examination of Water and Wastewater, $22^{\text {nd }}$ Edition. Editor E.W., Rice R.B., Baird A.D., Eaton L.S. (eds). Clesceri. American Public Health Association, Virginia.

Apriadi, T., \& Ashari, I. (2018). Struktur Komunitas Fitoplankton pada Kolong Pengendapan Limbah Tailing Bauksit di Senggarang, Tanjungpinang. Majalah Ilmiah Biologi Biosfera-A Scientific Journal, 35(3), 145 - 152.

Aryani, R., \& Apriadi, T. (2018). Inventory of Epiphytes Aquatic Microfungi in Pond of Tailing Bauxite in Tanjungpinang, Bintan Island, Riau Islands Province. OmniAkuatika, 14 (3), 106-111.

Asriyana \& Yuliana. (2012). Produktivitas Perairan. Bumi Aksara. Jakarta.

Barber, R. T., \& Hilting, A. K. (2002). History of the Study of Plankton Productivity. In: P. J. B. Williams, D. N. Thomas, \& C. S. Reynolds (eds). Phytoplankton Productivity: Carbon Assimilation in Marine and Freshwater Ecosystems. Blackwell Science. Oxford, UK. p. 16-43.

Borra, C.R., Blanpain, B., Pontikes, Y., Binnemans, K. \& van Gerven, T., (2016). Recovery of Rare Earths and Other Valuable Metals from Bauxite Residue (Red Mud): A Review. Journal of Sustainable Metallurgy, 2(4), 365 - 386.

Carignan, R., Blais, A. M., \& Vis, C. (1998). Measurement of Primary Production and Community Respiration in Oligotrophic Lakes Using the Winkler Method. Canadian Journal of Fisheries and Aquatic Science, 55, 1078-1084.

Dash, S., Patra, A. K., \& Adhikari, S. (2011). Primary Productivity of Kharasrota River (India). Journal Ecophysiology and Occupational Health, 11(3-4), 219-225.

Davis, C. C. (1955). The Marine and Fresh Water Plankton. Michigan State University Press. Michigan, USA.

Elser, J. J., Bracken, M. E. S., Cleland, E. E. , Gruner, D. S., Harpole, W. S., Hillebrand, H., Ngai, J. T., Seabloom, E. W., Shurin, J. B., \& Smith, J. E. (2007). Global Analysis of 
Nitrogen and Phosporus Limitation of Primary Producers in Fresh Water, Marine, and Terresterial Ecosystem. Ecology Letter, $10,1-8$.

Graham, J. M., Arancibia-Avila, P., \& Graham, L. E. (1996). Physiological ecology of a species of the filamentous green alga Mougeotia under acidic conditions: Light and temperature effects on photosynthesis and respiration. Limnology Oceanography, 41(2), 253-262.

Hardiyanto, R., Suherman, H., \& Pratama, R. I. (2012). Kajian produktivitas primer fitoplankton di Waduk Saguling, Desa Bongas dalam kaitannya dengan kegiatan perikanan. Jurnal Perikanan dan Kelautan, 3(4), 51-59.

Huszar, V. L. M. \& Reynolds, C. S. (1997). Phtyoplankton Periodicity and Sequences of Dominance in an Amazonian Flood-Lain Lake (Lago Batata, Para, Brasil): Responses to Gradual Environmental Change. Hydrobiologia, 346 (1-3), 169-181.

Kaswadji, R. F., Widjaja, F., \& Wardiatno, Y. (1993). Produktivitas Primer dan Laju Pertumbuhan Fitoplankton di Perairan Pantai Bekasi. Jurnal Ilmu-ilmu Perairan dan Perikanan Indonesia, 1 (2), 1-15.

Keeney, D. R. (1973). The Nitrogen Cycle in Sediment-Water System 1. Journal of Environmental Quality, 2(1),15-29.

Krebs, C. J. (2014). Ecological Methodology, $3^{\text {rd }}$ ed. Online access. Retrieved fromhttp://www.zoology.ubc.ca/ krebs/boo ks.html.

Mizuno, T. (1979). Illustrations of the Freshwater Plankton of Japan. Hoikusha Publishing Co.Ltd. Japan.

Odum, E. P. (1993). Dasar-Dasar Ekologi. Edisi Ketiga. Diterjemahkan oleh T. Samingan, dan B. Srigandono. Gajah Mada University Press. Yogyakarta. xv +697 hal.

Peraturan Pemerintah Republik Indonesia No. 82 Tahun 2001 Tentang Pengelolaan Kualitas Air dan Pengendalian Pencemaran Air.

Puspita, L., Ratnawati, E., Suryadiputra, I. N. N., \& Meutia, A. A. (2005). Lahan Basah Buatan di Indonesia. Wetlands International -Indonesia Programme. Bogor.

Putra, R. D., Apriadi, T., Suryanti, A., Irawan, H., Raza'i, T. S., Yulianto, T., Putra, W. K. A., \& Koenawan, C. J. (2018). Preliminary Study of Heavy Metal ( $\mathrm{Zn}, \mathrm{Pb}, \mathrm{Cr}, \mathrm{As}, \mathrm{Cu}$, Cd) Contaminations on Different Soil Level From Post-Mining Bauxite Production for Aquaculture. E3S Web of Conferences 47, 02008. SCiFiMaS.

Schindler, D. W. (1977). Evolution of Phosporus Limitation in Lakes. Science,195(4275), 260-262

Sembiring, S. (2008). Sifat Kimia dan Fisik Tanah pada Areal Bekas Tambang Bauksit di Pulau Bintan, Riau. Info Hutan, (V)2, 123-134.

Wardoyo, S. E., \& Ismail, W. (1998). Aspek Fisika Kimia dan Biologi Kolong-Kolong di Pulau Bangka untuk Pengembangan Perikanan. Jurnal Penelitian Perikanan Indonesia, 4 (2), 75-85.

Zulfikar, A. (2015). Analisis Kandungan Logam pada Limbah Tailing (Red Mud) Tambang bauksit. Dinamika Maritim.http://riset.umrah.ac.id/?p=509.

Zulfikar, A., Azizah, D., \& Melani, W. R. (2015). Perbandingan Kadar Logam Berat Limbah Cair Bauksit di Sei Carang Kelurahan Kampung Bugis Kabupaten Bintan.Dinamika Maritim. Retrieved fromhttp://riset.umrah.ac.id/?p=512. 